\title{
Küre Dağları Milli Parkı'nda Uygulanan Kırsal Kalkınma Projelerinin Sonuçlarının Değerlendirilmesi
}

\author{
Damla YILDIZ ${ }^{1}$, Erdoğan ATMİş ${ }^{2 *}$ \\ ${ }^{1}$ Karabük Üniversitesi, Orman Fakültesi, Orman Mühendisliği Bölümü,78050, Karabük \\ ${ }^{2 *}$ Bartın Üniversitesi, Orman Fakültesi, Orman Mühendisliği Bölümü,74100, Bartın
}

\section{Öz}

Bartın ve Kastamonu yörelerindeki çeşitli sivil toplum kuruluşlarının (STK) sunduğu beş proje, Küresel Çevre Fonu’nun (GEF) 2008-2012 yıllarını kapsayan Orman Koruma Alanları Yönetiminin Güçlendirilmesi Projesi (PIMS 1998) ve "Örnek Uygulamalar Programı" kapsamında desteklenmiştir. Bu çalışmada, projeleri desteklenen STK'ların deneyimlerinin incelenmesi ve desteklenen projelerin hangi oranda hayata geçirilebildiğinin araştırılması amaçlanmıştır. Bu kapsamda, söz konusu projelerin başvuru dosyaları ile ara dönem değerlendirme, saha ziyaret ve sonuç raporları incelenmiştir. Buna ek olarak, projelerin uygulandığı sahalarda yüz yüze görüşmeler gerçekleştirilmiş̧ir. $\mathrm{Bu}$ çalışmanın bulgularına göre, söz konusu projeler olan "Ekoturizm Tabanlı Ev Pansiyonculuğunun Geliştirilmesi”, "Elektrikli Çit ile Tarımsal Üretim Alanlarının Korunması", "Tarımsal Ürün Pazarlamanın İyileştirilmesi”, "Geleneksel Kültürün Korunması ve Kadın Emeğinin Değerlendirilmesi”, "Keten İşlemeciliğinin Desteklenmesi” projelerinin tümünün başarıya ulaştığını ve yöre halkı tarafından sürdürüldügünü̈ söylemek çok güçtür. Bu tür projelerin hayata geçirilmesinin kolaylaştııılması ve sürdürülebilir kırsal kalkınmanın desteklenebilmesi için yöre halkının bu tür projelere daha etkin katılımını sağlayacak yöntemlerin geliştirilmesi gereklidir.

Anahtar Kelimeler: Doğa turizmi, geleneksel kültür, kadın emeği, korunan alan, tarımsal ürün.

\section{Assessment of Rural Development Projects Implemented at Küre Mountains National Park}

\begin{abstract}
Presented by various non-governmental organizations in Bartin and Kastamonu area, five projects were supported in the scope of Global Environment Fund's (GEF) Strengthening of Forest Protection Areas Management Project (PIMS 1998) and "Examplary Practices Program". In this study, it was aimed to investigate the experiences of those NGOs whose projects' were supported and the success rate of their projects. In this context, application dossiers of the supported projects, their interim reports, field visit reports and final reports were examined. In addition, face-to-face interviews were conducted in the areas where those five projects had been carried out. According to the findings of this study, it is very difficult to say that all of the above-mentioned namely, "Development of Ecotourism-based Home Boarding", "Protection of Agricultural Production Areas with Electric Fences", "Improving Marketing of Agricultural Products", "Protection of Traditional Culture and Utilisation of Women's Labor", "Supporting Linen Processing" have been successful and have been continued to be sustainably by the local people. It is necessary to improve the methods that aim for more effective participation of the local people in such projects in order to facilitate implementation of such projects and to support sustainable rural development.
\end{abstract}

Keywords: Ecotourism, traditional culture, women’s labor, protected area, agricultural product. 


\section{Giriş}

Doğa korumanın geleceği kırsal alanların geleceğine, kırsal yaşam tarzının korunmasına ve sağlıklı bir kırsal ekonomiye bağlıdır (Anonim, 2007). Avrupa Komisyonu tarafindan hazırlanan Türkiye 2018 yılı İlerleme Raporu'nda tarım ve kırsal kalkınmanın desteklenmesi konusuna önem verilmesi gerektiğine değinilmiştir (Anonim, 2018). 2014-2018 yıllarını kapsayan 10. Kalkınma Planı'nda kırsal kalkınma politikasının temel hedefi; kırsal kesimin sahip olduğu olanakların iş ve yaşam koşullarının bulunduğu yörede iyileştirilmesidir (Anonim, 2013). Ayrıca 11. Kalkınma Planı (2018-2023)'ndaki "Yaşanabilir Şehirler ve Sürdürülebilir Çevre” başlığı altında, ekonomik ve sosyal faydanın artırılmasına paralel olarak çevrenin korunması, şehirlerde ve kırsal alanlarda yaşam kalitesinin iyileştirilmesi ile bölgeler arası gelişmişlik farklarının azaltılmasına yönelik hedef ve politikalara yer verilmektedir (Anonim, 2019). Bu planda, kırsal kesimdeki yaşam biçimlerinin korunması amacıyla tabiat ve kültür varlıklarının da korunmasını sağlayacak tedbirler alınacağı belirtilmektedir. Bu kapsamda köylere özgü el sanatları, agro-turizm, coğrafi işaretli ürünler, geleneksel üretim ve saklama yöntemleri konuları başta olmak üzere pek çok alanda yapılacak çalışmalardan bahsedilmektedir. Ayrıca kalkınma planlarında korunan alanlar ve buna bağlı kırsal turizm etkinlikleri; kırsal kalkınmanın önemli bir parçası olarak gösterilmektedir (Günşen ve Atmiş, 2020).

Türkiye’nin önemli ekoturizm merkezlerinden olan ve 07.07.2000 tarihinde korunan alan olarak ilan edilen Küre Dağları Milli Parkı, ülkedeki 46 milli parktan biridir (DKMP, 2021). Küre Dağları Milli Parkı (KDMP) ulusal ve uluslararası düzeyde öneme sahiptir. WWF katkılarıla 1999'da belirlenen, Avrupa'da korunması gereken 100 orman sıcak noktasının 9'u Türkiye'dedir ve bunlardan biri Küre Dağları Milli Parkı'dır (Lise, 2011). Küre Dağları Milli Parkı'nı diğer milli parklardan ayıran en önemli özellik; bu milli parkın koruma ve planlama sürecinde Türkiye'de ilk defa etkin katılımcı yöntemler uygulanarak sınırlarının herkesin ortak kararıyla belirlenmiş olması ve sınırları dışında yer alan resmi planlama ünitesi olarak tampon bölge barındırmış olan tek milli park olmasıdır (KDMP, 2021).

Küre Dağları Milli Parkı, korunan alanların yönetiminde kalitenin arttırılması ve kırsal kalkınmanın teşvik edilmesini sağlamayı amaçlayan, fakat daha sonra iflas eden PAN Parks sertifikasyon sistemine katılmış olan Avrupa'nın 13. ve Türkiye'nin de ilk ve tek milli parkıdır (Atmiş, 2009; Akbulut vd., 2015; Görmüş vd., 2015). Ayrıca, 2019 yılında Merkezi Avusturya'da olan "European Wilderness Society" tarafından "Platinum Wilderness Certificate" (Platin Yabanıl Sertifika) ödülünü almıştır (URL-1, 2019). KDMP Türkiye'nin 311 "Önemli Doğa Alanı"ndan biridir (UNDP, 2010) ve WWF tarafından Türkiye'de 122 Önemli Bitki Alanı'ndan biri olarak belirlenmiştir. Bunlara ek olarak KDMP'nin doğa koruma açısından küresel düzeyde öncelikli 200 ekolojik bölgeden biri olan Kuzey Anadolu ve Kafkasya Ilıman Kuşak Ormanları içinde yer aldığı ifade edilmektedir (KDMP, 2021).

Küresel Çevre Fonu (GEF) destekli 29 Mayıs 2008-Haziran 2012 yıllarını kapsayan Orman Koruma Alanları Yönetiminin Güçlendirilmesi Projesi (PIMS 1998) kapsamında Küre Dağları Milli Parkı ve tampon bölgesinde doğa koruma, sürdürülebilir doğal kaynak kullanımı, sürdürülebilir turizm uygulamalarında başarılı örnekler oluşturmayı amaçlayan "Örnek Uygulamalar Programı” gerçekleştirilmiştir (KDMP, 2012). Bu bağlamda Bartın ve Kastamonu yörelerindeki sivil toplum kuruluşlarına yönelik hibe duyurusu yapılarak bölgedeki sivil toplum kuruluşlarının sunduğu 5 proje desteklenmiştir. Desteklenen bu projeler, bu çalışmada örnek olarak seçilmiştir.

KDMP'de Orman Koruma Alanları Yönetiminin Güçlendirilmesi Projesi kapsamında çeşitli örnek uygulamalar yapılmıştır. Fakat bu örnek uygulamaların sonuçlarını değerlendiren araştırma sayısı çok azdır. Bunlardan birinde Akbulut (2012); Küre Dağları Milli Parkı çevresindeki Ulus ilçesinde halihazırda ev pansiyonculuğu yapılan 10 adet evin bulunduğunu, görüşme gerçekleştirilen köy muhtarlarının \%6'sının köylerinde pansiyonculuk faaliyetlerinin olduğunu belirttiğini bildirmiş ve Düzköy, Ulukaya ve Abdurrahman gibi köylerde kültürel değerlerin devamlılı̆̆ının sağlanması açısından halıcılık faaliyetlerinin desteklenmesi gerektiği önerisinde bulunmuştur.

Bu çalışma; Orman Koruma Alanları Yönetiminin Güçlendirilmesi Projesi kapsamında Küre Dağları Milli Parkı ve tampon bölgesinde yapılan "Ekoturizm Tabanlı Ev Pansiyonculuğunun Geliştirilmesi Projesi”, "Elektrikli Çit ile Tarımsal Üretim Alanlarının Korunması Projesi”, “Tarımsal Ürün Pazarlamanın İyileştirilmesi Projesi”, "Geleneksel Kültürün Korunması ve Kadın Emeğinin Değerlendirilmesi Projesi” ve "Keten İşlemeciliğinin Desteklenmesi Projesi” isimlerini taşıyan beş projenin başarı düzeyini ve bu projelerin hayata hangi oranda geçirilebildiğini araştırmak amacıyla yapılmıştır. Bu kapsamda; bu projelerin mevcut durumlarının ortaya konması, mevcut deneyimlerin analizi ile uygulayıcıların kazanımlarının ve memnuniyetlerinin araştırılması hedeflenmiştir. 


\section{Materyal ve Metot}

Bu çalışmada; “Küre Dağları Milli Parkı'nda Uygulanan Orman Koruma Alanları Yönetiminin Güçlendirilmesi Projesi” kapsamında yer alan Örnek Uygulamalar Programı'ndaki projeler hakkında detaylı bilgilere ulaşılmaya çalışılmış ve bu proje konularıyla ilgili ulusal ve uluslararası ölçekte yapılmış araştırmaların incelenmesini içeren ayrıntılı bir kaynak taraması gerçekleştirilmiştir. Elde edilen bilgiler doğrultusunda, çalışmada ilk olarak Birleşmiş Milletler Kalkınma Programı Türkiye Ülke Ofisi (Ankara) ve Tarım ve Orman Bakanlığı yetkilileriyle iletişime geçilmiş ve konu ile ilgili uzmanlarla Ankara'da görüşülerek, bilgi ve fikir alışverişinde bulunulmuştur. Ayrıca bu projelerde çalışan proje yöneticileri, uzmanlar, proje uygulayıcıları ve projeden yararlananlar gibi bazı paydaşlarla konu hakkında yüz yüze veya telefon ve e-posta aracılığıyla bilgi alışverişinde bulunulmuştur.

Örnek Uygulama Programlarının her biri ile ilgili başvuru dosyalarına (Anonim, 2010), ara dönem değerlendirme saha ziyareti raporlarına (Anonim, 2011) ve sonuç raporlarına (Anonim, 2012a) ulaşılmış ve bu raporlar ayrıntılı olarak ve derinlemesine incelenmiştir. $\mathrm{Bu}$ raporlar, örnek uygulama projelerinin uygulayıcıları ve yararlanıcılarına sahada sorulacak soruların oluşturulması konusuna 1şık tutmuştur. Ayrıca söz konusu raporlarda yararlanıcıların kimler olduğuna dair bilgilerin yer almaması ve proje başvurusu yapan derneklerin çoğunun pasif durumda olması nedeniyle ilgililere ulaşmada zorluk yaşansa da, hemen hemen hepsine ulaşılıp gerekli görüşmeler başarıyla yapılmıştır.

Çalışmada görüşme grubunu “Küre Dağları Milli Parkı’nda Uygulanan Orman Koruma Alanları Yönetiminin Güçlendirilmesi Projesi” kapsamında yer alan Örnek Uygulamalar Programı'ndaki 5 örnek uygulama projesinin yararlanıcıları oluşturmaktadır. Araştırmada kullanılan yöntem olasılığa dayalı olmayan (önyargılı) örnekleme yöntemlerinden Kartopu örneklemesidir. Kartopu örneklem yapmak için, herhangi bir şekilde evrene dahil birisiyle temas kurulur. Sonra temas kurulan kişinin yardımıyla bir başkasıyla, daha sonra yine aynı yolla bir başkasıyla temas kurulur. Kartopu etkisi şeklinde, zincirleme olarak örnek büyütülür (Coşkun vd., 2015; Gürbüz ve Şahin, 2018). Bu yöntem deneklerin çok fazla bilinmediği ve ulaşılması güç denekleri örnekleme dahil etmek bakımından oldukça yararlıdır (Gürbüz ve Şahin, 2018).

Örnek uygulamalar programı kapsamında desteklenen proje yararlanıcıları bilgileri, proje yararlanıcılarından görüşülenlerin sayısı ve proje yararlanıcılarıyla görüşme şekli Tablo 1'de gösterilmiştir.

Tablo 1. Örnek uygulamalar programı kapsamında desteklenen proje uygulayıcıları, yürütücüleri ve yararlanıcıları ile gerçekleştirilen görüşme ve görüşme şekli.

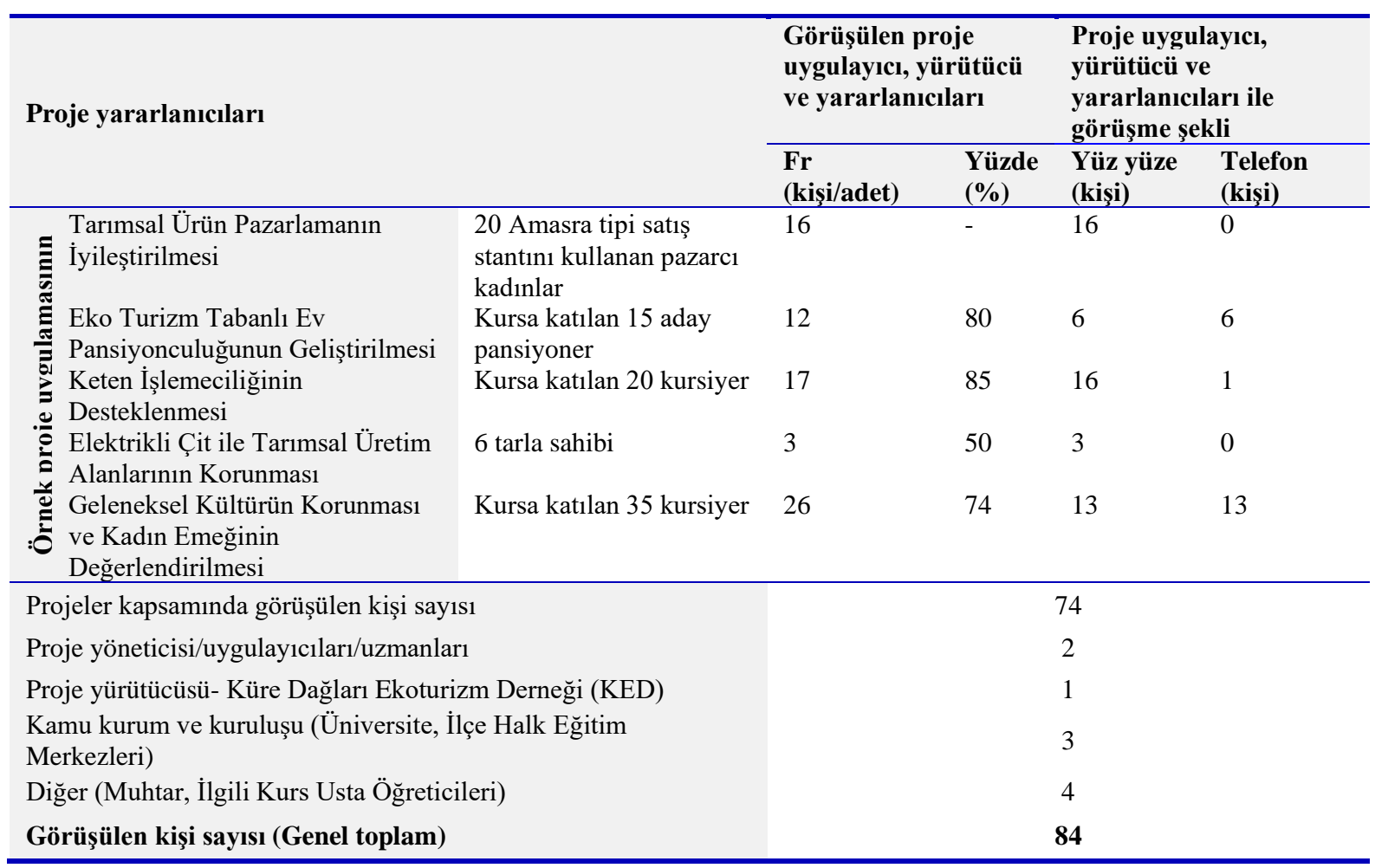


Örnek uygulamalar programı kapsamında desteklenen bu projelerin adı, yürütücüsü, proje katkısı, bütçesi, özet/çıktısı, uygulanan bölgeler ve uygulandığı yıllar Tablo 2'de gösterilmişstir.

Tablo 2. Örnek uygulamalar programı kapsamında desteklenen projelere ait ayrıntılı bilgiler.

\begin{tabular}{|c|c|c|c|c|c|c|c|}
\hline \multirow{2}{*}{$\begin{array}{l}\text { Örnek proje } \\
\text { uygulamasının } \\
\text { adı }\end{array}$} & \multirow{2}{*}{$\begin{array}{l}\text { Proje } \\
\text { yürütücüsü }\end{array}$} & \multicolumn{2}{|c|}{ Proje katkısı (TL) } & \multirow{2}{*}{$\begin{array}{l}\text { Toplam } \\
\text { bütçe (TL) }\end{array}$} & \multirow{2}{*}{$\begin{array}{l}\text { Projelerin } \\
\text { uygulandığı } \\
\text { yıllar }\end{array}$} & \multirow{2}{*}{$\begin{array}{l}\text { Proje } \\
\text { özeti/ } \\
\text { çıtısı }\end{array}$} & \multirow{2}{*}{$\begin{array}{l}\text { Uygulanan } \\
\text { bölge }\end{array}$} \\
\hline & & GEF & Dernek & & & & \\
\hline $\begin{array}{l}\text { Tarımsal Ürün } \\
\text { Pazarlamanın } \\
\text { İyileştirilmesi }\end{array}$ & $\begin{array}{l}\text { Ulus İlçesi } \\
\text { Aşağıçerçi } \\
\text { Köyü } \\
\text { Kalkındırma- } \\
\text { Güzelleştirme } \\
\text { Ortak } \\
\text { Mallarını } \\
\text { Yaptırma ve } \\
\text { Yaşatma } \\
\text { Derneği } \\
\text { (AÇDER) }\end{array}$ & $18.500,00$ & $2.500,00$ & $21.000,00$ & \multirow[t]{2}{*}{$\begin{array}{l}\text { Projelerin örnek } \\
\text { uygulamalar } \\
\text { Başvuru } \\
\text { Belgelerinde ve } \\
\text { Sonuç } \\
\text { Raporlarında söz } \\
\text { konusu projelerin } \\
\text { hangi yıllar } \\
\text { arasında başladığı } \\
\text { ve bittiği } \\
\text { konusunda } \\
\text { herhangi bir net } \\
\text { bilgi } \\
\text { bulunmamaktadır. }\end{array}$} & $\begin{array}{l}\text { Pazar } \\
\text { yerine } \\
\text { konulan } \\
\text { satış ürün } \\
\text { stantları }\end{array}$ & Ulus/Bartın \\
\hline $\begin{array}{l}\text { Eko Turizm } \\
\text { Tabanlı Ev } \\
\text { Pansiyonculuğun } \\
\text { un Geliştirilmesi }\end{array}$ & $\begin{array}{l}\text { Drahna Çevre } \\
\text { Kalkınma } \\
\text { Eğitim Kültür } \\
\text { ve } \\
\text { Dayanışma } \\
\text { Derneği } \\
\text { (DrahnaDer) }\end{array}$ & $18.150,00$ & $7.250,00$ & $25.400,00$ & & $\begin{array}{l}\text { Ev } \\
\text { pansiyonc } \\
\text { uluğu } \\
\text { yapacak } \\
\text { kapasiteye } \\
\text { ulaşmış } 15 \\
\text { hane }\end{array}$ & Ulus/Bartın \\
\hline $\begin{array}{l}\text { Keten } \\
\text { İşlemeciliğinin } \\
\text { Desteklenmesi }\end{array}$ & $\begin{array}{l}\text { Bartın ve } \\
\text { Çevresinde } \\
\text { Yaşayan } \\
\text { Uluslular } \\
\text { Kültür } \\
\text { Dayanışma } \\
\text { ve } \\
\text { Yardımlaşma } \\
\text { Derneği }\end{array}$ & $10.760,00$ & 450,00 & $11.210,00$ & \multirow[t]{3}{*}{$\begin{array}{l}\text { Sadece Başvuru } \\
\text { Belgelerinde } \\
\text { proje süresi } 8 \text { ay } \\
\text { olarak belirtilmiş } \\
\text { ve Ara Dönem } \\
\text { Değerlendirme } \\
\underline{\text { Saha Ziyareti }} \\
\underline{\text { Raporlarının } 17-} \\
\begin{array}{l}21 \text { Ağustos } 2011 \\
\text { tarihleri arasında }\end{array} \\
\text { olduğu bilgisine } \\
\text { ulaşılmıştır. }\end{array}$} & $\begin{array}{l}\text { Mengenez } \\
\text { makinas1 } \\
\text { yapımı ve } \\
\text { keten } \\
\text { işleme } \\
\text { ünitesi }\end{array}$ & $\begin{array}{l}\text { Hoca köyü- } \\
\text { Ulus/Bartın }\end{array}$ \\
\hline $\begin{array}{l}\text { Elektrikli Çit ile } \\
\text { Tarımsal Üretim } \\
\text { Alanlarının } \\
\text { Korunması }\end{array}$ & $\begin{array}{l}\text { Bartın ve } \\
\text { Çevresinde } \\
\text { Yaşayan } \\
\text { Uluslular } \\
\text { Kültür } \\
\text { Dayanışma } \\
\text { ve } \\
\text { Yardımlaşma } \\
\text { Derneği }\end{array}$ & $25.500,00$ & $19.025,00$ & $44.525,00$ & & $\begin{array}{l}6 \text { tarlada } \\
\text { toplam } 300 \\
\text { dekarlık } \\
\text { alanda } \\
\text { elektrikli çit } \\
\text { uygulamas1 }\end{array}$ & Ulus/Bartın \\
\hline $\begin{array}{l}\text { Geleneksel } \\
\text { Kültürün } \\
\text { Korunması ve } \\
\text { Kadın Emeğinin } \\
\text { Değerlendirilmesi }\end{array}$ & $\begin{array}{l}\text { Küre Dağları } \\
\text { Ekoturizm } \\
\text { Derneği }\end{array}$ & $52.745,00$ & $18.800,00$ & $71.545,00$ & & $\begin{array}{l}35 \text { kadına } \\
\text { eğitim ve } \\
\text { eğitim } \\
\text { sonrası } \\
\text { belgeler } \\
\text { ile çok } \\
\text { sayıda } \\
\text { farkl1 } \\
\text { hediyelik } \\
\text { eşya } \\
\text { üretimi }\end{array}$ & $\begin{array}{l}\text { Pınarbaş1- } \\
\text { Azdavay/ } \\
\text { Kastamonu }\end{array}$ \\
\hline
\end{tabular}

Eylül 2019'da uygulayıcılardan istenen proje belgelerine Kasım 2019'da ulaşılmıştır. Böylece elde edilen her bir örnek uygulama programının başvuru dosyaları, ara dönem değerlendirme saha ziyareti raporları ve sonuç raporlarında verilen bilgi ve verilerin analizi gerçekleştirilmiştir. Ulaşılan kısıtlı ve eksik bilgilerle sahada görüşmelere başlanamayacağından yüz yüze olarak veya telefon aracılığıyla ön görüşmeler gerçekleştirilerek, eksik/yetersiz bilgiler toplanıp tamamlanmaya çalışıldı. "Ekoturizm Tabanlı Ev Pansiyonculuğunun 
Geliştirilmesi Projesi” hakkında bilgi edinme noktasında ilk önce DRAHNADER'in yayımlanmasına yardımcı olduğu ve ekoturizm tabanlı ev pansiyonculuğunun tanıtıldığı broşüre ulaşılmıştır. Projede yer alan ev pansiyonlarının adı, pansiyonun bulunduğu köy ile pansiyonerlerin iletişim bilgilerinin hatta fotoğraflarının yer aldığı broşür sayesinde pansiyonerlere ulaşılmıştır. Elektrikli çit projesinden yararlandığı tespit edilen Ulus ilçesi Arpacık Köyü eski muhtarı Ali Çelik’ten alınan diğer yararlanıcıların isim ve bilgilerinden yararlanılarak bu kişilerle önce telefon görüşmeleri yapılmış, daha sonra da saha ziyareti sırasında yüz yüze görüşmeler gerçekleştirilmiştir. “Tarımsal Ürün Pazarlamanın İyileştirilmesi Projesi” için özellikle projedeki stantlar öncesi, projedeki stantlar sırasında ve stantlar kaldırıldıktan sonra olmak üzere her üç dönemde de mevcut yerinde satış yapan pazarcı kadınlarla görüşmeler yapılması tercih edilmiştir. Proje kapsamında konulan stantlar öncesi satış yapmayan ve projedeki stantlarda da satış yapmayanlarla görüşme yapılmamıştır. "Geleneksel Kültürün Korunması ve Kadın Emeğinin Değerlendirilmesi Projesi” kursiyerlerinin katılımcı listesi ve iletişim bilgileri ise Azdavay Halk Eğitim Merkezi yetkilileri sayesinde elde edilmiştir. "Keten İşlemeciliğinin Desteklenmesi Projesi" nden yararlanan kursiyerler hakkındaki bilgiler ise Ulus ilçesi Hocaköy muhtarı ve aynı zamanda keten projesinde kursiyer olan Şenol YAĞCI ile yüz yüze görüşülerek elde edilmiştir.

Örnek uygulamalar programı kapsamında desteklenen projelerden yararlananların demografik özelliklerini, kurs kapsamında aldıkları teorik ve uygulamalı eğitimlerden memnuniyetlerini, proje uygulama faaliyetlerinin talep ve beklentilerini ne oranda karşılandığını, proje öncesi ve sonrası yaşadıklarını, uygulamadaki yetersizlikler ve/veya engelleri ve proje faaliyetlerini uygulamada hangi düzeyde hayata geçirdiklerini saptamak için örnek uygulama projelerinin her biriyle ilgili ayrı ayrı 5 farklı görüşme formu hazırlanmıştır. Görüşmelere; Bartın Üniversitesi Sosyal ve Beşeri Bilimleri Etik Kurulu tarafından izni verilen 05.11.2020 tarihli "Etik Kurul Onay" belgesinin verilmesinden sonra başlanmıştır. 4 Şubat 2021 tarihinde başlanan görüşmeler yüz yüze ve telefon aracılığıyla aynı ay içerisinde gerçekleştirilmiştir.

Görüşmeler bizzat projelerin gerçekleştirildiği uygulama yerlerinde “Yüz yüze” yapılmış, fakat sahada kendisine ulaşılamayan veya o yıllarda projede yer aldığı halde, sonradan başka yerlere göç etmiş olan kişilerin iletişim bilgilerine ulaşılarak, bu kişilerle “Telefon” aracılığıyla görüşülmüştür. Böylece 74'ü proje yararlanıcısı olan toplam 84 kişiyle görüşmeler grçekleştirilmiştir.

\section{Bulgular}

\subsection{Projeler}

Bu bölümde projeler hakkında kısa bilgiler verilecektir. Projelere ait proje özeti, proje gerekçeleri, proje stratejisi ile proje hedef göstergelerine ait bilgiler, her bir projenin proje raporundan alınmıştır.

\subsubsection{Ekoturizm tabanlı ev pansiyonculuğunun geliştirilmesi projesi}

Projenin temel hedefi doğrultusunda, Küre Dağları Milli Parkı tampon zonunda yer alan köylerde ekoturizmi geliştirmek amacıyla ev pansiyonculuğunun yaygınlaştırılması için 15 haneye 15 ünite yatak takımı verilmiştir. Ev pansiyonculuğu yapmaya elverişli geleneksel ahşap yapıların yaygınlığ 1 , turizm sektöründe çalışmaya istekli nüfus ve yöredeki insanların bu konuda çalışmaya yönelik talebi projenin tasarlanmasında önemli bir rol oynamıştır. Bölge potansiyeli dahilinde kalkınma aracı olarak ekoturizm en uygun sektör olarak görülmüş ve bu faaliyet kolunun istihdam yaratırken, aynı zamanda yörenin cazibe merkezi haline gelmesini de sağlayacağ1 düşünülmüştür. Göç verme oranının azaltılmasını hedefleyen projede, yörede yoğun olan yaşlı ve emekli nüfusun bu proje sayesinde tarımsal faaliyetler kadar beden gücü gerektirmeyen bir iş koluna sahip olabilmesi ve yörede daha önce yapılmış olan ekoturizmi destekleyici çalışmaların sürdürülebilirliğinin arttırılması hedeflenmiştir.

“Ev Pansiyonculuğu Kursu” 21 Haziran - 09 Temmuz 2010 tarihlerinde Ulus ilçesi Aşağıçerçi köyünde ve 23 Haziran - 09 Temmuz 2010 tarihlerinde Kozanlı köyünde IŞSUR Müdürlüğü ile usta öğreticiler eşliğinde gerçekleştirilmiştir. Aşağıçerçi köyünde gerçekleştirilen kursa 15 kursiyer, Kozanlı köyünde gerçekleştirilen kursa 23 kursiyer katılmıştır. Kurs sonunda 37 kişi sertifika almıştır.

Ev Pansiyonculuğu Kursu'nda verilen dersler;

- Misafir ilişkileri ve iletişim,

- Genel turizm ve pansiyonculuk,

- Doğa koruma, milli parklar ve ekoturizm,

- Ev pansiyonu açma işlemleri ve mali konular şeklindedir. 
Proje kapsamında Zonguldak'ın Devrek ilçesine ve Kaz Dağları'na eğitim gezileri düzenlenmiştir. Eğitimlerde; ev pansiyonculuğunun mali boyutu hakkında bilgiler verilerek, katılımcılarla yeşil işletmecilik örnekleri paylaşılmış ve proje kapsamında kurulacak konuk odalarının ileride yeşil ev pansiyonlarına dönüşmesi için ilk adımların da bu eğitimlerde atılması planlanmıştır.

Ekoturizm Tabanlı Ev Pansiyonculuğunun Geliştirilmesi Projesi, "Drahna Çevre Kalkınma Eğitim Kültür ve Dayanışma Derneği (DrahnaDer)" tarafından sunulan ve desteklenen bir projedir.

\subsubsection{Elektrikli çit ile tarımsal üretim alanlarının korunması projesi}

Bu proje, milli parkta yaşayan yaban hayvanlarının tarımsal üretim alanlarına verdiği zararları azaltmak amacıyla tasarlanmıştır. Küre Dağları Milli Parkı'nın tampon zonunda yer alan köylerde temel geçim kaynaklarından biri de tarımdır. Fındık ve silajlık mısır en fazla üretilen bitkisel ürünlerdir. Tarımsal üretimde maliyetlerin yüksek olması, genç nüfustaki azalış ve tarımın yapısından kaynaklanan sorunlar bu yörenin temel geçim kaynağı olan tarımı yeterince olumsuz etkilemektedir. Bununla birlikte yörede avlanması yasak olan bozayı ve yaban domuzunun tarımsal üretim alanlarına ve arı kovanlarına verdiği zararın, o bölgede yaşayan az sayıda çiftçinin tarımsal üretimden ve arıcılık faaliyetinden vazgeçmesine sebep olacak kadar artmaya başladığ (KDMP, 2010). Bu nedenle findık başta olmak üzere silajlık mısır ve bahçe bitkileri üretimi yapılan bahçeleri bu hayvanların saldırısından korumak için, bu bahçelerin elektrikli çitlerle çevrilmesi amaçlanmıştır. Tek gelir kaynağı olan tarımsal ürünlerinin yaban hayvanları tarafından yok edilmesinin, yöre halkının yaban hayvanlarına düşmanca tavır sergilemesine neden olduğunu belirtmekte fayda vardır (Anonim, 2012b; Yıldız ve Atmiş, 2019).

Arıcılık faaliyeti de yöredeki bir diğer önemli geçim kaynağını oluşturmaktadır. Bozayıların arı kovanlarına zarar verme olasılığı yüksek olduğu için, daha önce kovan konulan orman kenarlarına artık kovanların konulamaması, ayrıca bal verim ve kalitesinin yüksek olacağı alanların bozayı saldırısına en açık alanlar olması nedeniyle kovanların ev kenarlarına konulmak zorunda kalması ve yöredeki bal verim ve kalitesinin düşmesi bu projeyi gerektirmiştir. Bu proje ile tarımsal üretim alanları ile arıcılık yapılacak alanlar korunurken, yaban hayvanlarının zarar görmesi de engellenmek istenmiştir. Bu kapsamda 20 ünite elektrikli çitin en fazla risk altında olan köylere verilmesi hedeflenmiştir. Elektrikli çit her bir ünitede 15 dekarlık araziyi çevrelemektedir.

Bu proje, "Bartın ve Çevresinde Yaşayan Uluslular Kültür Dayanışma ve Yardımlaşma Derneği” tarafından yürütülen ve süresi 8 ay olan bir projedir.

\subsubsection{Geleneksel kültürün korunması ve kadın emeğinin değerlendirilmesi projesi}

Bu proje, Küre Dağları Milli Parkı Kastamonu ili tampon zonunda yer alan Azdavay ve Pınarbaşı ilçelerindeki yöre kadınlarının halen kullandıkları yöresel kıyafetlerinin kültürel bir değer olarak korunmasını ve kadın emeğinin değerlendirilerek kadınlara alternatif bir gelir kaynağı oluşturmayı hedeflemektedir. Projenin geliştirilme nedeni; “Küre Dağları Milli Parkı'nın sahip olduğu kültürel değerlerin korunmasını sağlamak, görünürlüğünü artırmak ve KDMP tampon zonunda var olan ekoturizm potansiyelini desteklemek” tir.

Geleneksel Kültürün Korunması ve Kadın Emeğinin Değerlendirilmesi Projesi kapsamında geleneksel giysilerin 2 uzman tasarımcı tarafından geliştirilen 27 farklı yeni ürünün yapımının yöre kadınlarına öğretilmesi amaçlanmıştır. Bu amaçla Azdavay ilçesinde 20 ve Pınarbaşı ilçesinde 15 kadın olmak üzere toplam 35 kadına, Azdavay ve Pınarbaşı'nda 10'ar gün olmak üzere toplam 20 gün kurs verilmesi hedeflenmiştir. Bu kapsamda Şenpazar ve Cide ilçelerinden toplam 30 kadının Azdavay ve Pınarbaşı ilçelerinde gerçekleştirilen çalışmaları görmeleri için kursların gerçekleştirildiği atölyeleri ziyaret etmesinin sağlanması da hedeflenmiştir. Proje süresince yapılan faaliyet ve oluşturulan bilgiler hakkında bilgi verecek bir ürün kataloğu çıkartılması, oluşturulan tüm ürünlerin gerçekleştirilecek sergi ve defilede yöre kadınları tarafından sergilenmesi, bu sergide geleneksel kıyafetlerin tarihini aktaran ve proje süresince yürütülen faaliyetleri anlatan 2 ayrı sunumun gerçekleştirilmesi iş planında yer almıştır.

Geleneksel Kültürün Korunması ve Kadın Emeğinin Değerlendirilmesi Projesi, "Küre Dağları Ekoturizm Derneği (KED)" tarafından sunulan ve desteklenen bir projedir.

\subsubsection{Keten işlemeciliğinin desteklenmesi projesi}

“Bartın ve Çevresinde Yaşayan Uluslular Kültür Dayanışma ve Yardımlaşma Derneği” tarafından KDMP tampon zonundaki Ulus ilçesine bağlı Hocaköy’de yürütülen bir projedir. Bu köyde sürmekte olan keten tarımının sürdürülebilirliğinin sağlanması ve keten işlemenin desteklenmesinin amaçlandığı projede; köy tüzel kişiliğine 
ait bir binanın keten işleme ünitesine dönüştürülmesi hedeflenmiştir.

Keten İşlemenin Desteklenmesi Projesi, "Küre Dağlarında Alternatif Bir Geçim Stratejisi Olarak Doğa Dostu Sürdürülebilir Keten Tarımı Başlangıç Projesi”nin devamı niteliğinde olup, ana hedefi KDMP tampon zonunda katma değeri yüksek tarımsal üretimin ve bölgedeki geçim kaynaklarının sürdürülebilirliğinin desteklenmesidir. Birinci projede 20 çiftçi toplam 100 ha alanda keten üretmeye başlamış ve devamı niteliğindeki diğer projeyle de hasat edilen ketenlerin katma değeri artırıcı faaliyetlerinin gerçekleştirilmesi planlanmıştır. Proje başvurusunda keten işlemenin bölgede yaygınlaştırılmak istenmesinin nedenlerinden biri olarak "arzdan fazla talebin olması" şeklinde ifade edilmektedir.

\subsubsection{Tarımsal ürün pazarlamanın iyileştirilmesi projesi}

"Ulus İlçesi Aşağıçerçi Köyü Kalkındırma-Güzelleştirme Ortak Mallarını Yaptırma ve Yaşatma Derneği”" tarafından uygulanan bu proje; tarımsal ürünlerin daha modern koşullarda satışına imkan sağlayacak ürün satış stantlarının köylülerin kullanımına verilmesini sağlamayı amaçlamıştır. Bu proje; Ulus pazarındaki kadınların daha önce satışlarını yere oturarak ve ürünlerini de yere koyarak yaptığı için, kadınların sağlıssız bir ortamda satış yaptığı ve bu durumun hijyen açısından olumsuz bir ortam oluşturduğu tespitinden hareketle oluşturulmuştur. Temin edilen satış stantları ile kadınların sandalyede oturarak tezgahta satış yapmaları sağlanmış, ürünlerin de yerden yüksekte, daha temiz bir ortamda satışa sunulması mümkün olmuştur. Projede her bir satış stantının bir köye tahsis edilmesi düşünülmüş ve stantların üzerinde KDMP yazısı ve proje ortaklarının logoları ile köyün isminin yer alması planlanmıştır. Böylece ürünün hangi köye ait olduğunun belli olması istenmiştir. Bu uygulama köy ürünlerinin markalaşması için de bir adım niteliğindedir. Böylece toplam 20 köyün kendine ait bir satış stantı olması ve bu stantların köylülerin ortak kullanımına sunulması sağlanmıştır.

\subsection{Saha gözlemleri ve görüşme sonuçları}

\subsubsection{Ekoturizm tabanlı ev pansiyonculuğunun geliştirilmesi projesi}

Ekoturizm Tabanlı Ev Pansiyonculuğunun Geliştirilmesi Projesi’nden, daha önce kursa gidip sertifika almaya hak kazanan 15 aday pansiyoner yararlanmıştır. Aday pansiyoner olmaya ve konuk adası kurmaya hak kazanan bu proje yararlanıcılarının \%86,66'sı (13 kişi) kadındır. Bu kişilerin, kurmayı düşündükleri pansiyonlarının bulunduğu köyde ortalama 42,5 y1l ikamet ettikleri belirlenmiştir.

Pansiyonerlerin çoğu bu işi Köklü Konağı'ndaki İsmail ve Mehmet YILMAZ kardeşlerin yapmaya devam ettiğini, turistlerin orayı tercih ettiğini iddia etmektedir. Bu kardeşlerle yapılan görüşmelerde, ev pansiyonculuğu uygulamasını aktif olarak sürdürmeye çalıştıkları, hatta Köklü Konağı dışında ilgi çekici tasarımlarla zenginleştirilen bir konaklama ve yeme-içme yerini daha tesis etmiş oldukları görülmüştür.

Projeden yararlanan 12 aday pansiyonerle yüz yüze ve telefonla yapılan görüşmelerin verileri analiz edildiğinde şu bulgulara ulaşılmıştır;

- Projeden genel olarak dernek aracılığıyla, özelde Galip Arslan ve Ercan Yeni sayesinde haberdar oldukları,

- Projeden edindikleri bilgileri arkadaşları ve komşularıyla paylaştıkları,

- Bu uygulamada dernek dışında kimseden yardım almadıkları, özellikle dernek başkanı (Galip Arslan) vefat ettikten sonra bu konularda pasif kalındığı bildirilmiştir. Ama yine de dernek yönetiminin proje katılımcılarını Devrek ve Kazdağları'na götürerek ev pansiyonculuğu uygulaması konusunda onlara cesaret kazandırdığını, "Gidin-gezin-görün siz de yaparsınız" diyerek de onları bu uygulamayı gerçekleştirmek için teşvik ettiğini de söylemişlerdir.

- Katılımcılar almış oldukları eğitimleri olumlu bulduklarını, fakat ev pansiyonculuğunun ekonomik anlamda katkılarını görmediklerini, istihdam yaratılamadığını ve çalışmaların sistemli şekilde yürümediğini,

- Yeni bilgiler kazandıklarını, eğitimlerin tekrarlanmasını kısmen istediklerini, eğitim ve gezilerin kişisel gelişimlerine katkı sağladığını ve özellikle Devrek ve Kazdağları gezisinin çok verimli geçtiğini,

- Bu uygulamanın getirisi olarak; eğitim süresi boyunca günlük verilen ücret ile verilen ücretsiz bazanın kendilerine ekonomik katkı sağlamasının yanı sıra, yeni insanlarla tanışıp sosyalleşerek ve özgüven kazanarak kişisel gelişimlerine katkı sağladıklarını,

- Mevcut durumda ev pansiyonculuğu uygulamasını başarısız olarak değerlendirdikleri,

- Derneğin pansiyoner adı, iletişim bilgileri ve resimlerinin olduğu bir tanıtıcı broşür bastırdığı, birkaç pansiyoner (İsmail ve Mehmet YILMAZ kardeşler) dışında kimsenin kartvizit bastırmadığı, kimsenin kişisel web sayfasının olmadığı, radyo-TV reklamları ve haberlerde yer alınmadığı, 
- Tanıtım eksikliği, kadınların uygulamada aktif rol almaması/alamaması ve potansiyel konuk talebinin oluşmamasının uygulamadaki en önemli yetersizlikler ve/veya engeller olarak görüldüğü iddia edilmiştir.

Proje uygulamaları hakkındaki tespit ve gözlemler ise şunlardır;

- Kriterlere uygun gönüllü aileler tespit edilmiş, bilgilendirme toplantıları yapılmış, örnek odalar oluşturulmuş ve yataklar tedarik edilerek evlere ulaştırılmıştır.

- Zonguldak-Devrek ve Kaz Dağları'na eğitim gezileri düzenlenmiş ve aday pansiyonerler bu gezilerden çok memnun kalmıştır.

- Proje faaliyetlerinde KDMP Konuk Evi kurucuları ile odalar kurulmadan önce ve proje sonunda olmak üzere 2 adet anket gerçekleştirileceği belirtildiği halde, KDMP Konuk Evi kurucuları ile herhangi bir anket çalışması yapılmadığı katılımcılar tarafından ifade edilmiştir.

- Konuk Evlerine ziyarete gelen turistlerin proje kapsamında dolduracağı anketler bırakılmamış ve/veya bırakıldıysa da bu anketlere bu çalışma sırasında ulaşılamamıştır.

- Konuk evlerinde tüm tabelalarda "KDMP Konuk Evi” ibaresinin yer almasının planlandığı tabelaların tasarımı, yapımı ve monte edilmesi faaliyetleri gerçekleştirilmemiştir.

- Daha önce ev pansiyonculuğu kursuna katılanların bilgilerini pratiğe dönüştürmelerini öngören hedefe ulaşılamamıştır.

- İzleme-Değerlendirme-Raporu hazırlanmamış ve/veya yapıldıysa da bu rapora bu çalışma sırasında ulaşılamamıştır.

\subsubsection{Elektrikli çit ile tarımsal üretim alanlarının korunması projesi}

Projede bahsi geçen 6 tarladan 4'ü incelenmiştir. Bu kişilerden biriyle vefat etmiş olduğu için görüşülemezken, diğer 3 kullanıcı ile görüşülmüştür. Görüşmelerde elde edilen bilgilere göre;

- Elektrikli çit uygulaması katılımcıların beklentilerini karşılamış ve bu uygulamadan memnun kalınmıştır. Katılımcıların uygulamada yaşadıkları en büyük sıkıntı kullanıcılara iki farklı güçte akü verilmiş olduğu halde, bunlardan birinin küçük olduğu için yetersiz kalması nedeniyle daha büyük bir akü alınmak zorunda kalınmasıdır.

- Proje katılımcıları elektrikli çit uygulamasını proje kapsamı dışındaki tarlalarında da denemek istemektedir. Hatta komşularının da tarlalarını elektrikli çitle çevirme taleplerinin olduğunu aktarmışlardır. Bu çalışma kapsamında yapılan köy ziyaretleri sırasında, araştırmacıların konuyla ilgisi olmadığı halde araştırmacılara da bu yönde talepler gelmiştir.

- Katılımcılar elektrikli çitten önce tarlalarını yaban hayvanlarından özellikle bozayı ve yaban domuzundan ilkel yollarla (avlu çekme, telle/dikenle telle koruma, germeç germe, tarlalarına daha sık gidip gelme, gece sabaha kadar bekleme vb.) koruduklarını bildirmişlerdir.

- Katılımcılar tarafından elektrikli çitle çevirdikleri alanlara yaban hayvanı girmemiş olduğu beyan edilmiştir.

- Katılımcılar elektrikli çit uygulamasını başkalarına da önermektedir.

- Proje yetkililerinin verdiği danışma ve bilgilendirme hizmetlerinden memnun kalındığı ifade edilmişstir.

Projenin uygulandığı Arpacık köyünde yapılan incelemelere göre; tarla sahiplerinden birinin çitle çevrili tarlasını çok uzak olduğu ve eskisi gibi tarım yapamadığ 1 gerekçesiyle artık ekmediği ve elektrikli çit malzemelerini ambara koymuş olduğu tespit edilmiştir. İki tarla sahibinin ise hem aktif olarak tarıma devam etmekte, hem de hala tarlalarını elektrikli çitle korumakta olduğu gözlemlenmiştir. Vefat etmiş olan tarla sahibinin eşi ve çocuklarının köyden göç etmiş olduğu, terkedilmiş olan tarlasında proje kapsamında yapılmış olan direkler ve elektrikli çitlerin yıkık dökük de olsa tarlada mevcut olduğu görülmüştür.

Proje uygulamaları hakkındaki tespit ve gözlemler ise şunlardır;

- Bilgilendirme toplantıları gerçekleştirilmiş, elektrikli çitle korunacak alanlar seçilmiş ve işletmeler tespit edilmiştir.

- Elektrikli çit üniteleri alınmış, kazıklar çakılmış ve elektrikli teller monte edilmiştir.

- Proje kapsamında hazırlanmış olan tanıtım levhalarının tarlalarda halen bulunduğu, hatta kullanılmayan tarlada bile tanıtım levhasının yerinde durduğu görülmüştür.

- Uygulamada yaşanan olumsuzluklar olarak; bu tarz bir çalışmanın ilk olmasından dolayı köylülerin projeye başta şüpheyle yaklaşmış olması, sıra kazık temini işinin tarla sahiplerine yüklenmiş olması, ayrıca göçler nedeniyle genç nüfusun azalması ve tarımın terk ediliyor olması gösterilmiştir. 


\subsubsection{Geleneksel kültürün korunması ve kadın emeğinin değerlendirilmesi projesi}

“Geleneksel Kültürün Korunması ve Kadın Emeğinin Değerlendirilmesi Projesi” kapsamında Pınarbaşı ve Azdavay ilçelerindeki Halk Eğitim Merkezlerinde "Dekoratif Ev Aksesuarları Hazırlama Kursu” adı altında bir kurs açılmış ve kursiyerlere usta öğreticiler aracılığıyla eğitim verilmiştir. Proje etkinliklerinden yararlanmış olan 35 kursiyerin hepsi kadındır. Kursa katılanlara herhangi bir ücret verilmemiştir.

Bu çalışmada kursa katılan ve sertifika alan toplam 35 kursiyerden 26'sına (\%74,3) ulaşılmış, yüz yüze veya telefon aracılığıyla görüşmeler yapılmıştır. Görüşülen 26 kursiyerden 14'ünün uygulamaya devam etmediği, 2'sinin evde dikip satmaya devam ettiği ve 10'unun ise kurs öncesi bildikleri ve kursta öğrendikleri bilgilerle evde kendi ihtiyacını karşılayacak kadar dikiş yaptığı tespit edilmiştir. 15 kursiyerin evde dikiş makinesi vardır. Birinin elindeki dikiş makinesinin bozulmuş olduğu ve 10 kursiyerin ise evde dikiş makinesi olmadığ öğrenilmiştir. Kursiyerlerin 21'i sosyal güvencesi olmadığını, 5’i ise sosyal güvenceye sahip olduğunu belirtmiştir. Kursa katılan ve sertifika alan 35 kursiyerin yaş ortalaması 46,8'dir.

Projeden yararlanarak kursa katılan ve sertifika alan 35 kursiyerden 26'sıyla gerçekleştirilen görüşmeler değerlendirildiğinde;

- Proje faaliyetleri kapsamındaki geleneksel ürünlerin ulusal ölçekte temsilinin sağlanamadığı, fakat kısmen de olsa yöre halkında farkındalık oluştuğu,

- Projenin katılımcılara ekonomik bir katkısının olmadığı,

- Elbiselerini kendilerinin tasarlayıp dikemediği ve bu nedenle ucuza giyinemedikleri,

- Geleceğin ustalarının yetişmesi ve kültürün sürdürülebilirliğine katkı sağlayacak bir durumun oluşmadığ1,

- Başarıya ulaşılamamasının nedeni olarak; uygulamadaki yetersizlikler, altyapı eksikliği, tanıtım sorunu, kadınların pasif olması ve girişimcilik sergileyememelerinin gösterildiği,

- Kadınların kurs ücreti alamamalarına rağmen kursu önemli gördükleri ve neredeyse her gün kursa katıldıkları, fakat buna rağmen kurstan sonra herhangi bir alternatif iş olanağı oluşmadığı, bu işi birkaç kişinin dışında devam ettirenin olmadığı,

- Kurs sırasında Pınarbaşı/Azdavay kumaşlarıyla çok farklı çeşit ve modelde yapılan hediyelik eşyalar (önlük, çanta, bozay1- domuz- karaca- baykuş- horoz gibi hayvan figürleri, mantar, perde, bebek, masa örtüsü, polar vb) diktiklerini ama bunların pazarlanmadığını, satışa sunulmadığını, diktiklerini atölyede bıraktıklarını ve sonrasında ne durumda olduklarını bilmediklerini,

- Katılımcılardan neredeyse hiç birinin kişisel web sayfası, atölye, internet ortamında iletişim ve adres bilgileri, tanıtıcı broşür, radyo ve tv reklamlarında ve haberlerinde yer alma, kartvizit bastırma, vakıf/dernek, kooperatifleşme, yöresel hediyelik eşya pazarı, sergi/fuar/festival/kermes katılım ve ürün patenti gibi etkinlik ve uygulamalara sahip olmadığg1,

- Uygulamanın gelişmesi ve yaygınlaşması açısından desteklenmesi gereken durumlar olarak; kursların süresinin daha uzun olması ve kursta diktiklerinin pazarının oluşturulmasıyla ekonomik anlamda rahatlama/fayda sağlayabilmeleri gerektiği, bunun için atölye ve yöresel hediyelik eşya pazarı kurulmasını elzem gördükleri dile getirilmiştir.

Kurstan sonra, proje uygulama faaliyetleri arasında yer alan "Yapılan tasarımların tescilini yaptırmak" şeklinde ifade edilen faaliyet gerçekleştirilememiş, kısacası kurs sırasında yapılan tasarımlar/ürünler için herhangi bir ürün patenti alınamamıştır. Fakat Azdavay Belediye Başkanlığı tarafından Azdavay yöresel kıyafeti için 12.11.2020 tarihinde "Coğrafi ișaret" alınmış ve tescil edilmiştir (URL-2, 2020). Ayrıca, 2012 yılında yapılan bu kursun devamı niteliğinde bir proje yapılmasının planlandığı ve Belediye-Kaymakamlık-Dernek (KED) işbirliğinde bir atölye kurulması, pazarlama ağı oluşturulması ve böylece geleneksel kültürün korunmasının yanı sıra kadın emeğinin de değerlendirilmesi gibi düşüncelerin olduğu bildirilmiştir.

Proje sonuç raporunda geçen "Dernek tarafından uygulama kapsamında üretilmiş olan ürünlerin tanıtımları gerçekleştirilecek ve ürünler Küre Dağları Milli Parkı'nın tanıtımı için belirlenen satış alanlarına düzenli olarak gönderilecektir." şeklindeki uygulama faaliyetlerine saha çalışmalarında rastlanılmamıştır. Kadınlar kurs sonrasında projeyle ilgili hiç kimseyle iletişim kuramamış, ekonomik anlamda rahatlama sağlanmamış ve ne yazık ki kursta öğrendikleriyle kalmışlardır.

İncelenen belgelerde projede kullanılmak üzere Pınarbaşı ve Azdavay'a 10'ar adet olmak üzere toplam 20 adet dikiş makinesi alındığı şeklinde bir bilgiye ulaşılmıştır. Ancak kursiyerler; bu kursa katılanlara dikiş makinelerinin onlara evlerine götürmeleri için verileceği, kursiyerlerin diktiklerinin pazarda sunularak zamanla para kazanacakları şeklindeki vaatler sunulduğunu, fakat bu vaatlerin hiçbirinin yerine getirilmediğini ifade etmişlerdir. Bu kapsamda kursiyerlerin kursta yaptıklarının bir yerde sergileneceği veya zamanla satılarak kendilerine para kazandıracağ 


\subsubsection{Keten işlemeciliğinin desteklenmesi projesi}

Ulus Hocaköy'de geçmişte neredeyse tüm hanelerin keten üretimi yaptı̆̆ı ketenden çeşitli ürünler elde edildiği dile getirilmiştir. İmece usulüyle, toplu halde tek tek elle yolunarak yapılan keten üretiminin köy kalabalıkken çok zor gelmediği fakat yaşanan göçler nedeniyle nüfusun azalmasıyla keten üretiminin zorlaştığı belirtilmiştir. Literatürde keten tarımının canlandırılması, üretiminin artırılması ve işlemeciliğinin geliştirilmesini destekleyen çalışmalar (Anonim, 2017; Arslanoğlu vd., 2018; Tüm Cebeci, 2019) bulunmaktadır. Örneğin; Hocaköy'deki projeden sonra 2018-2019 yıllarında Ege Üniversitesi'nden gelen 3 akademisyen keten ile ilgili kendi projelerinde, önceki projede yer alan 20 çiftçinin yer almasını sağlamıştır. Akademisyenler çiftçilere tohumu temin etmiş̧ler ve ekme parası vermişler, keten ekildikten sonra, hasat dönemi geldiğinde ketenleri çiftçilerden toplamışlardır. Bu akademisyenlerden, Ege Üniversitesi Tekstil Mühendisliği Bölümü’nde görev yapan Dr. Burcu Karaca Uğural ile yapılan telefon görüşmesinde; "Hocaköy'ün toprağının keten tarımı için çok uygun olduğunu, buna rağmen iş yaptırmak için çalş̧acak insan bulmakta zorlandıklarını, çiftçilerin işi sahiplenmediğini ve hasat geciktiği için liflerin sert olduğunu" ifade etmiştir. Ayrıca; "Çiftçilerin hasadı takip edemediği ve doğru zamanda haber vermediği, nakliyat sorunu yaşandığı, bitkinin kökü ile tohumunun birbirine girdiği, kök ile lifler karışmış olduğu için lif işleme makinesine sokulunca verim düşüklüğü yaşandığı, fakat yine de bu köydeki ürünün yağ oranının \%30 olarak bulunduğu" belirtilmiştir.

Keten işlemeciliğinin desteklenmesi projesinde yer alan sertifikalı kursiyerlerle yapılan görüşmelerin neredeyse tamamı Hocaköy'de ve yüzyüze gerçekleştirilmiştir. Keten kursuna katılan ve keten üretiminde deneyim kazanan kursiyerlerin 16'sı kadın, 4'ü erkektir. Bu kişilerin ortalama yaşları 53,8'dir.

Proje uygulamaları hakkındaki tespit ve gözlemler ise şunlardır;

- Verilen eğitimlerden genel olarak memnun kalındığ 1 ve kursun verimli geçtiği ifade edilmiştir.

- Yörede keten üretimi yapılacak potansiyel alanlarının olduğu, fakat potansiyel işgücünün bulunmadı̆̆ bildirilmiştir. Görüşülenlerin ortalama yaşlarına bakıldığında bu sonucun çıkması normaldir.

- Katılımcıların neredeyse tamamı keten üretimi yapmayı bırakmış ve zaten keten işlemenin önemli bir geçim kaynağı olacağını da düşünmemektedir.

- Projenin keten tarımını pek de teşvik etmediği, proje ile keten tarımının canlanmadığı hatta projeden sonra keten üretimi yapmak için yeni girişimlerin olmadığı belirtilmiştir.

- Ellerinde yerli keten tohumunun çok az olduğu ve/veya hiç bulunmadığ ifade edilmiş̧tir.

- Proje faaliyetlerinde bildirildiği gibi keten işleme ünitesinin onarılmasına rağmen projeden sonra kullanılmadığı, mengenez makinasının ise temin edildiği ama proje sırasında ve sonrasında bile bu makinanın aktif kullanılmadığı hatta mengenez makinasını görmeyen/bilmeyen kurs katılımcılarının olduğu belirtilmektedir.

\subsubsection{Tarımsal ürün pazarlamanın iyileștirilmesi projesi}

Projedeki stantlardan o zamanlar yararlanan ve hala pazarda satış yapan kadınların çoğu ev kadınıdır. Yaş ortalaması 59,4 olan bu kadınlar, pazarda ortalama 28,3 yıldır satış yapmaktadır.

Kadınlar pazar yerindeki stantlarda şu ürünleri satmaktadırlar;

- Kendi ürettiği sebzeler: Kabak, marul, ıspanak, pırasa, domates, salatalık, fasulye, bakla, maydanoz, nane, biber, bamya, lahana, soğan, turp.

- Kendi bahçesindeki meyveler: Elma, armut, findık, ceviz, töngel (muşmula).

- Süt ürünleri: Süt, yoğurt, keş, tereyağı, peynir.

- Doğadan toplanan tali ürünler: Kızılcık (kiren), mantar, kuşburnu, ihlamur, 1spit.

- Ev yapımı yöresel gıdalar: Erişte, tarhana, mısır unu, helva, köy ekmeği, patlak mısır, kırık mısır, marmelat, tarhana, elma-armut-kozalak pekmezi, kuşburnu marmelatı, salça, makarna, gözleme, börek, yufka.

- Diğer: Yumurta, tohum ve fide satışı.

Şu anki gelinen noktada ise bu stantların kaldırıldığı ve kadınların artık Ulus Belediyesi'nin yaptırdığı stantlarda satış yaptığ 1 gözlenmiştir. Eski stant yerleri ise yerini kıyafet satanlara bırakmıştır. Kadınlar yeni yapılan stantlardan eski stantlara göre daha çok memnun olduklarını fakat bu stantların eski yerlerine konması gerektiğini ifade etmişlerdir. Stantların şimdiki yerinin "Ücra olduğu, uzak kaldığı, köşede-sapa kaldığı, burayı tanıyan olmadığı ve müşterinin ayağının alışık olduğu eski yeri istedikleri vb" düşüncelerini dile getirmişlerdir.

“Tarımsal Ürün Pazarlamanın İyileştirilmesi Projesi” kapsamında pazarda 10 yıldan fazladır satış yapan ve 
stantları kullanan 16 kişiyle gerçekleştirilen görüşmelerde genel bir memnuniyetsizlik olduğu belirlenmiştir. Ayrıca söz konusu projenin sonuç raporunda belirtildiği üzere pazarcı kadınlar gerçekleştirilen bu görüşmelerde; stantların boylarının kısa olduğunu, müşterilerin stantların yakınına giremediklerini ve stant genişliklerinin ürünlerin sergilenmesi için yeterli olmadığını dile getirmişlerdir. Benzer şekilde bu araştırma kapsamında pazarcı kadınlarla gerçekleştirilen görüşmelerde de yukarıda bahsi geçen proje kapsamında yapılan ve mevcut durumda kaldırılan stantlardan pek de memnun kalmadıklarını dile getirmişlerdir. Her ne kadar bu stantlar öncesi taşlar üzerinde, çamur içinde ve hijyenden uzak koşullarda satış yaptıklarını kabul etseler de belediyenin verdiği yeni stantları daha önce proje kapsamında sağlananlara göre daha çok beğendiklerini ifade etmişlerdir. Belediyenin yaptığı bu stantların tek olumsuz yanı eski yerinde olmamalarıdır. Söz konusu stantlarla ilgili bu üç durum k1yaslanırsa;

- Stantlar yapılmadan önce taşın üzerine oturarak satış yaptıklarını, çamur-su içinde olduklarını hatta ıslandıklarını, şemsiye ve/veya muşamba-naylon-çadır ile yağmur-kar-güneş-rüzgardan korunmaya çalıştıklarını,

- Stantların yapılması ile beton döküldüğü için çamurdan kurtulduklarını, oturacak yerlerinin olduğunu, daha sağlıkl1-hijyenik koşullarda satış yaptıklarını fakat yine de stantların yanları açık olduğu için üşüdüklerini, zamanla stantların üstlerinin açıldığını ve kendi çabalarıyla muşamba-çadır örttüklerini ama yine de fayda etmediğini, stantların akıttığını, kırıldığını, aynı köyden satıcılar olarak sadece bir stantta sıkış sıkış oturduklarını hatta 2-3 kişi olunca yer kavgası yaptıklarını, projede bahsedildiği gibi stant sahiplenmesi olmadığını, dahası bazılarına stant düşmediğini, stantların küçük geldiğini ve temizliğe dikkat edilmediğini,

- Belediyenin yaptırdığı stantlardan ise kurulduğu yere olan memnuniyetsizlik dışında genel memnuniyet duyulduğunu, herkesin stant numarasının olduğunu, kimsenin yerinin kapılmadığını ve belediyenin bunu takip ettiğini, stant sayısının yeterli olmasından dolayı ürünlerini rahat rahat sergilediklerini, stantların yanları-arkaları-üstleri kapalı olduğundan üşümediklerini, stantların daha sıcak ve büyük olduğunu, Belediyenin alanın temizliğine dikkat ettiğini belirtmişlerdir.

Proje uygulamaları hakkındaki tespit ve gözlemler ise şunlardır;

- Proje kapsamında satın alınmış olan stantlar mevcutta pazar yerinden kaldırılmıştır.

- $\quad$ Projede belirtildiği gibi stant verilecek köyler tespit edilmiş ama köylere verilecek günlük kayıt formu aktif olarak kullanılmamıştır.

- Stantların dağıtımı gerçekleştirilmiş fakat eşit dağıtılmamıştır.

- Stantlar mevcutta ilk yerleştirildikleri yerde değillerdir.

- Yeni Pazar stantlarında "Küre Dağları Milli Parkı” ibaresi veya logosu yer almamaktadır.

Yapılan görüşmelerde ortaya çıkan en önemli sonuçlardan biri de; her ne kadar stant öncesi koşullar iyileştirilmiş olsa da pazarcı kadınların stantlara çok da fazla anlam yüklemediğidir. Ilk kurulduğu zamanlarda stantların üzerinde bulunan Küre Dağları Milli Parkı levhası sorulduğunda çoğunun farkında bile olmadığı dikkati çekmiştir. Bu nedenle projedeki stantların kurulum amaçlarından bir tanesi olan; "Yörede Küre Dağları Milli Parkı hakkında farkındalığın artmasına katkıda bulunmak" hedefinin göz ardı edildiği ve yukarıda bahsedilen planlara uyulmadığ 1 gözlenmiştir.

\section{Tartışma ve Sonuç}

$\mathrm{Bu}$ çalışma aracılığıyla; Küre Dağları Milli Parkı çevresinde yapılmış 5 farklı projeye katılmış olan kişilerin uygulamalar hakkındaki düşünceleri öğrenilmiş, uygulamaların hangi düzeyde hayata geçirildiğine ilişkin bilgiler edinilmiş, uygulamadaki eksiklikler tespit edilmeye ve bu uygulamaların bölgesel kalkınmaya ne gibi katkıları olduğu sorgulanmaya çalışılmıştır. Bulgulara göre; Küresel Çevre Fonu (GEF) destekli 2008-2012 yıllarını kapsayan Orman Koruma Alanları Yönetiminin Güçlendirilmesi Projesi (PIMS 1998) ile "Örnek Uygulamalar Programı” kapsamında desteklenen, Bartın ve Kastamonu yörelerindeki sivil toplum kuruluşlarının sunduğu projelerin sonuçları, kazanımları, uygulamaya katılanların memnuniyet düzeyleri ile ilgili izleme ve değerlendirme çalışmaları oldukça yetersizdir.

“Ekoturizm Tabanlı Ev Pansiyonculuğunun Geliştirilmesi Projesi” birkaç aday pansiyonerin çabaları dişında hayata geçirilememiştir. Proje raporlarında da belirtildiği gibi belirlenen haneler ekonomik kazanç sağlanabilecek ev pansiyonu durumuna getirilememiştir. Oysa bu tür çalışmaların; ev pansiyonlarında çalışılarak kazanılan gelirin köy kadınlarının bağımsız olarak para kazanmasını sağlayacağı ve kendilerine güveni arttıracağı bildirilmektedir (Akyol, 2012). Ayrıca Çalık ve Zurnacı (2019) çalışmalarında, ev pansiyonculuğunun kırsal bölgelerde yerel 
halkın refahına katkı sağlayan ekonomik bir unsur olduğunu belirtmektedir. Yöredeki tarihi evlerin turizm işletmesi biçimine dönüştürülmesi (restoran ve pansiyon) süreçlerinde yer alan ve el işlerine dayalı faaliyet gösteren kadınların, kırsal turizmde göz ardı edilemez katkısı olduğu ve kırsal bölgenin lokomotifi durumunda, tarihi, turistik ve yerel geleneklerini sürdüren bir güce sahip konumda yer aldıkları iddia edilmektedir (Fidan ve Nam, 2012).

"Elektrikli Çit ile Tarımsal Üretim Alanlarının Korunması Projesi” nden yararlananların genel olarak memnuniyet düzeylerinin yüksek olduğu fakat sonrasında bu uygulamanın da takibinin yapılmadığı tespit edilmiştir. Zaten uygulama çok az sayıda katılımcıyla yapılmış, uygulamadan haberi olan diğer köy sakinleri de benzer çalışmaların yapılmasını talep etmiş, fakat ne yazık ki bu uygulamalar yaygınlaştırılamamıştır. Tarımsal üretimin devamlılığının desteklenmesi adına bu tür uygulamaların yaygınlaştırılması çok önemlidir.

“Tarımsal Ürün Pazarlamanın İyileştirilmesi Projesi” için yapılan stantların, kısa ömürlü olması ve oldukça erken kaldırılması, proje için oluşturulan stantların teknik eksiklikler taşımasından ve bu stantları ortak kullanmak zorunda kaldıkları için katılımcılar tarafından yeterince benimsenmemiş olmasından kaynaklanmıştır. Bunların yerine Ulus Belediyesi tarafından inşa edilen yeni stantlarda KDMP'ye ait bilgi ve sembollerin bulunmaması, projenin sonuçlarının çok kısa ömürlü olduğunun göstergesidir. Oysa Ulus Belediyesi’nin, proje kapsamında hizmete konmuş olan stantların yetersizliğini görüp, yenilerini yapmış olsa bile, yeni stantlarda da KDMP'ye ilişkin bilgilere yer vermiş olması bu süreyi uzatabilir ve KDMP'nin tanıtımını sürekli hale getirebilirdi.

“Geleneksel Kültürün Korunması ve Kadın Emeğinin Değerlendirilmesi Projesi” kursiyerleri her ne kadar kursa katılmaktan memnun olsalar da, bu kurslardan bir gelir elde edemedikleri ve öğrendiklerini sürekli şekilde hayata geçiremedikleri için bu memnuniyetin uzun sürmediğini belirtmişlerdir. Gerçekten de bu tür kursların sonuçlarının sürdürülebilir olması, proje kapsamında kursiyerlere öğretilen bilgilerin, kursiyerler tarafından sürekli kullanılmasının sağlanmasına bağlıdır. Tabii ki yapılacak üretimin sürekliliğini sağlamak için de, kurs sırasında bu ürünlerin tanıtımını ve pazarlamasını sağlayacak mekanizmaların oluşturulması gerekir.

Göç nedeniyle neredeyse boşalan köylerde yöre kadınlarının geleneksel giyim davranışlarından vazgeçmemeleri; bayramlarda, şenliklerde ve yazın gelen diğer aile bireylerinin yine aynı elbiseleri 1srarla giymeleri, bu elbiselere olan talebin sürekliliğini göstermektedir. Ayrıca turizmin yaratacağı ilgiyle oluşacak talebin de devreye girmesiyle, bu elbise ve oyuncaklara yönelen talep artacak ve sürekli hale gelebilecektir. Proje çıktılarının bu şekilde "kadınların gelir elde etmelerine yardımcı olması"; yöre halkının ve özellikle kadınların refahı ve huzuru için çok önemli olduğu gibi (Koç, 2019), kadınların ekonomik anlamda karşılaşmış olduğu engelleri rahat bir şekilde aşmasında örgütlü olmanın ve kooperatifleşmenin önemini de göstermektedir (İlter vd., 2019).

“Keten İşlemeciliğinin Desteklenmesi Projesi” geçmişte de keten üretiminin yapıldığı ve ketenden ürün elde edildiği alanlarda tekrar ketenin canlandırılması açısından önemlidir. Proje ile tamiri yapılan keten işleme ünitesi ve mengenezin neredeyse hiç kullanılmadı̆̆ 1 ve kursiyerlerin faydalanmasına sunulmadığı gözlenmiştir. Oysa; keten bitkisinin tohumundan hayvanlar için küspe yapmanın yanı sıra yağ elde edildiği, ilaç niyetine kullanıldı ̆̆ ve çok lezzetli olduğu bilinmektedir. Keten bacaklarından sarım (demir-boru için), lif, ip, döşek, bez, kumaş, gömlek, kilim, divanların üzerine çöp yatağı/çöpür vb elde edildiği bildirilmiştir. Ege Üniversitesi’ndeki akademisyenler, keten elyaf kullanarak özellikle araç içi tasarımda hafiflik ve tasarruf sağlayacak alternatif bir malzeme geliştirmek üzere olduklarını söyleyerek keten üretiminin ne kadar önemli olduğunu ve sürekliliğinin sağlanması gerektiğinin altını çizmiştir (URL-3, 2018).

Kamu kurum ve kuruluşları ile yerel yönetimler keten üretiminin sürdürülebilir kırsal kalkınma aracı olmasında aktif rol alabilmektedir. Örneğin Ayancık ilçesindeki keten üretimi, 1960-1990'lı yıllara kadar önemli miktarda üretilirken 1990'lı yıllardan sonra önemli ölçüde düşmüş, 2000'li yılların başında ise üretim tamamen bitmiştir. Kaliteli ketenin yetiştirildiği ilçede; Kültür Turizm Müdürlüğü, Ayancık Kaymakamlığının girişimleri ile tekrar Ayancık keteninin ekimi yapılmıştır. Bu uygulama Ayancık İlçe Tarım ve Orman Müdürlüğü tarafından desteklenmiştir. Ayrıca Sinop Halk Eğitim Merkezi ve Kültür ve Turizm Müdürlüğü’nde yöresel dokuma atölyeleri ve kurslar yoluyla dokumacılık sanatının yaşatılmaya devam ettiği bildirilmiştir. Söz konusu sanatın yaşatılmaya devam edilmeye çalışılmasının yanı sıra Pervane Medresesi Geleneksel El Sanatları Çarşısı'nda özel dokuma ustaları ve Sinop Valiliği İl Kültür ve Turizm Müdürlüğü Yöresel El Sanatları Atölyesi'nde de geleneksel tezgahlarda dokuma işlemleri sürdürülmeye çalışıldığı da ifade edilmiştir (Tüm Cebeci, 2019). Bu açıdan benzer çalışmaların Bartın'ın Ulus ilçesinde de sürdürülmesi yararlı olacaktır.

Projelerin gerçekleştirildiği sahalar özellikle göçün ve işsizlik problemlerinin yaşandığı alanlardır. Uygulanan bu projelerin izleme ve değerlendirme çalışmalarının yeterince yapılmamış olması, bu tür dış kaynaklı projelerin sürdürülebilirliği noktasında olumsuzluklara neden olmaktadır. Bu tür projelerde halkın katılımının sembolik 
olarak kalması ve proje amacının sadece projeyi tamamlamaya odaklanması, bu projelerin verimli olmasını ve sürdürülebilir kazanımlar sağlamasını engellemektedir. Dış kaynaklı projelerin; proje yapmak ve uygulamaktan öteye, proje sonucu olarak hayata geçirilebilen çıtıtlar üretme potansiyeline sahip olması bir zorunluluktur. Aksi halde bu projeler; zaman, emek ve maddi kaynakların boş yere harcanmasından başka bir anlam taşımayacaktır.

Sadece dış kaynaklı projeler değil, kırsal kalkınmaya yönelik hazırlanan bütün projelerin, yukarıdan aşağıya doğru oluşturulmaları yerine, tabandan başlayarak oluşturulması gerekliliği, burada anlatılan beş projenin yanı sıra birçok proje sonunda karşı karşıya kalınan bir gerçekliktir. Yöre halkıyla birlikte kurgulanıp hazırlanmayan, aksine belli genel kalıplar çerçevesinden hazırlanmış olan projelerin başarıya ulaşması çok zordur. Ayrıca proje katılımcılarının projenin aktif bir parçası olmak yerine, pasif bir elemanı olmaları da projelerin başarıya ulaşmasını engellemektedir. Proje katılımcıları proje sürecinde aktif rol üstlenmeli ve proje sonrasında da bu etkililiklerini sürdürmelidir.

Bu çalışmada Küre Dağları Milli Parkı çevresinde yapılan projeler incelenmiştir. Bu tür projelerin başarıya ulaşıp ulaşmadıklarının ve hayata geçirilip geçirilmediğinin sorgulandığı çalışmaların sayısının arttırılması gerekmektedir. Ancak bu şekilde bu projelere harcanan emek, zaman ve maddi kaynakların karşılık bulması ile kırsal kalkınma konusunda kayda değer bir ilerleme sağlanabilir.

\section{Teşekkür}

Bu çalışma, Bartın Üniversitesi Bilimsel Araştırma Projeleri Koordinasyon Birimi tarafından 2019-FEN-A-017 numaralı “Küre Dağları Milli Parkı'nda Uygulanan Orman Koruma Alanları Yönetiminin Güçlendirilmesi Projesi Kapsamındaki Örnek Uygulamalar Programı Deneyimlerinin Değerlendirilmesi” adlı proje kapsamında desteklenmiştir. Bartın Üniversitesi Rektörlüğü ile Bilimsel Araştırma Projeleri Koordinasyon Birimi’ne ve değerli personeline teşekkür ederiz.

\section{Kaynaklar}

1. Akbulut, G. (2012). Küre Dağları Milli Parkı'nın Bartın Bölümü’ndeki Sosyo-Kültürel Yapının PAN Parks Çerçevesinde İncelenmesi. Yüksek Lisans Tezi, Bartın Üniversitesi Fen Bilimleri Enstitüsü, Orman Mühendisliği Anabilim Dalı, Bartın, 115 s.

2. Akbulut, G., Atmiş, E., Günşen, H. B. (2015). Farklı ilgi gruplarının milli park algıları üzerine bir değerlendirme: Küre Dağları Milli Parkı örneği. Kastamonu Üniversitesi Orman Fakültesi Dergisi, 15 (1): 133-145.

3. Akyol, C. (2012). Kırsal turizmde ev pansiyonculuğu modeli ve Karadeniz örneklemesi-Artvin. Uluslararası Sosyal ve Ekonomik Bilimler Dergisi (IJSES). 2 (2): 79-83. ISSN: 2146-5843, E-ISSN: 21460078

4. Anonim (2007). Türkiye'deki korunan alanlar ve çevresinde sürdürülebilir turizm gelişim stratejisi rehberi. Biyolojik çeşitlilik ve doğal kaynak yönetimi projesi yayınları. Ankara. $120 \mathrm{~s}$.

5. Anonim (2010). Orman koruma alanları yönetiminin güçlendirilmesi projesi örnek uygulamalar programı başvuru belgeleri.

6. Anonim (2011). Orman koruma alanları yönetiminin güçlendirilmesi projesi örnek uygulamalar programı ara dönem değerlendirme saha ziyareti raporları.

7. Anonim (2012a). Orman koruma alanları yönetiminin güçlendirilmesi projesi örnek uygulamalar programı sonuç raporları.

8. Anonim (2012b). Orman koruma alanları yönetiminin güçlendirilmesi projesi Küre Dağları Milli Park1 uzun devreli gelişme planı halkın katılımı toplantıları değerlendirme raporu. $76 \mathrm{~s}$.

9. Anonim (2013). Onuncu Kalkınma Planı (2014-2018). T.C Başbakanlık Devlet Planlama Teşkilatı, Kalkınma Bakanlığı yayını. Ankara. $199 \mathrm{~s}$.

10. Anonim (2017). Karadeniz’in lif bitkileri çalıştayı: Keten-kenevir-1sırgan. Samsun. 170 s.

11. Anonim (2018). Komisyon tarafından Avrupa parlamentosuna, konseye, ekonomik ve sosyal komiteye ve bölgeler komitesine sunulan bilgilendirme. Avrupa Komisyonu 2018 Türkiye raporu. $111 \mathrm{~s}$.

12. Anonim (2019). On Birinci Kalkınma Planı (2019-2023). T.C. Cumhurbaşkanlığı Strateji ve Bütçe Başkanlığı. Ankara. 209 s.

13. Arslanoğlu, Ş. F., Aytaç, S., Ayan, A. K. (2018). Keten; Anadolu Coğrafyasında Küllerinden Yeniden Doğan Bitki. Ziraat Bilimlerinde Güncel Akademik Çalışmalar. 1. Baskı. ISBN: 978-9940-540-48-7

14. Atmiş, E. (2009). PAN Parks sürecindeki Küre Dağları Milli Parkı için bir örnek: Majella Milli Parkı. Orman ve Av Dergisi. 85 (4): 8-14. 
15. Coşkun, R., Altunışık, R., Bayraktaroğlu, S., Yıldırım, E. (2015). Sosyal Bilimlerde Araştırma Yöntemleri SPSS Uygulamalı (8. bask1). Sakarya Kitabevi, Sakarya. ISBN: 978-605-4229-42-0

16. Çalık, İ., Zurnacı, J. (2019). Sürdürülebilir turizm göstergeleri bağlamında ev pansiyonculuğunun değerlendirilmesi: Yusufeli örneği. Journal of Tourism and Gastronomy Studies. 7 (3), 2144-2166. DOI: 10.21325/jotags.2019.465

17. DKMP (2021). Doğa Koruma ve Milli Parklar Genel Müdürlüğü. Korunan Alanlar. https://www.tarimorman.gov.tr/DKMP/Belgeler/Korunan\%20Alanlar\%20Listesi/1-\%20Milli\% 20Parklar. pdf, (Erişim tarihi: 10.02.2021)

18. Fidan F., Nam D. (2012). Kırsal turizmde yeni dinamikler: Kadın girişimciliği-Taraklı örneği, KMÜ Sosyal ve Ekonomik Araştırmalar Dergisi, 14 (23): 51-57. ISSN: 1309-9132.

19. Görmüş, S, Atmiş, E., Artar, M., Özkazanç, N. K., Günşen, H. B., Cengiz, S., Tekebas S. (2015). Küre Dağları Milli Parkı köy tasarım rehberleri (Bartın bölümü). Mutlu Basım Yayın, ISBN:978-605-9895-057, İstanbul.

20. Günşen, H. B., Atmiş, E. (2020). Kalkınma planlarında yer alan orman köylüsüne ilişkin politikaların zamansal değişimi. Bartın Orman Fakültesi Dergisi, 22 (1): 256-272

21. Gürbüz, S., Şahin, F. (2018). Sosyal bilimlerde araştırma yöntemi (5. baskı). Ankara: Seçkin Yayınevi. ISBN: 978-975-02-5127-6

22. İlter, B., Kundak, S., Cenikli, V. S. (2019). Sürdürülebilir kırsal kalkınmada bir alternatif olarak kadın girişimciliği: Afyonkarahisar örneği. Girişimcilik İnovasyon ve Pazarlama Araştırmaları Dergisi. 3(5):3037. DOI: $10.31006 /$ gipad.427872

23. KDMP (2010). Küre Dağları Milli Parkı Orman Koruma Alanları Yönetiminin Güçlendirilmesi Projesi Yaz Bülteni, E-bülten. 5 s.

24. KDMP (2012). Küre Dağları Milli Parkı Orman Koruma Alanları Yönetiminin Güçlendirilmesi Projesi Yaz Bülteni, E-bülten, 7. Say1. 16 s.

25. KDMP (2021). Küre Dağları Milli Parkı. https://www.kdmp.gov.tr/kurumsal/projeler (Erişim tarihi: 11.06.2021).

26. Koç, A. (2019). Geleneksel Kültürün Korunması ve Kadın Emeğinin Değerlendirilmesi: Kastamonu İli Azdavay-Pınarbaşı Örneği. Toplumsal Cinsiyet ve Kadın Folkloru Yazıları Kitabı, Paradigma Akademi, 95-105.

27. Lise, Y. (2011). https://yildiraylise.wordpress.com/2011/04/01/turkiyenin-orman-sicak-noktalari/. (10.02.2019).

28. Tüm Cebeci, D. (2019). Peşkir ve mahrama dokumalarının Sinop el dokumacılığındaki yeri. İdil Sanat ve Dil Dergisi. 61, s: 1187-1198. doi: 10.7816/idil-08-61-11

29. UNDP (2010). Küre Dağları Milli Parkı ziyaretçilere açıldı. Yeni Ufuklar Dergisi, UNDP Aylık Haber Bülteni, Say1 56.

30. URL-1 (2019). https://www.tarimorman.gov.tr/Sayfalar/Video Galeri.aspx?Kategori=f4715203-60dc4ac4-9f26-cc97e73d7636, T.C. Tarım ve Orman Bakanlığı. (Erişim tarihi: 12.02.2021).

31. URL-2 (2020). https://ci.turkpatent.gov.tr/cografi-isaretler/detay/1844, Türk Patent ve Marka Kurumu. (Erişim tarihi: 02.07.2021).

32. URL-3 (2018). https://www.trthaber.com/haber/bilim-teknoloji/keten-lifinden-enerji-dostu-malzemegelistirildi-386146.html (Erişim tarihi: 03.05.2021).

33. Yıldız, D., Atmiş, E. (2019). Türkiye'nin Korunan Alanlarında Çatışma Analizi. Bartın Orman Fakültesi Dergisi, 21 (1): 227-242. DOI: 10.24011/barofd.507088. 